\title{
Clinical and Molecular Features of Ewing Sarcoma in a Patient with Triple-X Syndrome
}

\author{
A. Patiño-García, R. López de Mesa, E. de Alava, and L. Sierrasesúmaga
}

From the Laboratory of Pediatrics (A. P.-G., R. L. d. M., L. S.), and the Department of Pathology (E. d. A.), University of Navarra, Pamplona, Spain.

Address reprint requests to: Dra. Ana Patiño-García, Laboratory of Pediatrics, University of Navarra, E31080 Pamplona, Spain.

\begin{abstract}
A case of Ewing sarcoma in a 16-year-old girl with 47,XXXc karyotype is reported.
\end{abstract}

\section{INTRODUCTION}

Ewing sarcoma has been demonstrated to be associated with specific chromosome changes in tumoral cells in more than $95 \%$ of the cases, the most frequent being the translocation $\mathrm{t}(11 ; 22)(\mathrm{q} 24 ; \mathrm{q} 12)$, which generates a gene fusion involving the EWS and FLI1 genes [1], but X chromosome abnormalities are rarely found in this kind of pediatric bone tumor [2].

We detected the 47,XXXc karyotype in a 16-year-old girl who was diagnosed and treated for Ewing sarcoma and who was eventually submitted for cytogenetic examination because she was included in an investigation protocol that is underway in the laboratory. To our knowledge, this is the first case report of an association of triple$\mathrm{X}$ karyotype with a Ewing sarcoma.

\section{CASE REPORT}

A 16-year-old girl was admitted to the Clínica Universitaria, Pamplona, in February 1998. The clinical symptoms began in September 1997 with leg pain, and MR imaging and CAT scan analysis revealed a tumor mass in the right thigh and bilateral lung metastases. She was diagnosed in November 1997 of an extraskeletal Ewing tumor with lung metastases. Preoperative chemotherapy consisted of alternate courses of cyclophosphamide $\left(500 \mathrm{mg} / \mathrm{m}^{2}\right)$, adriamycin $\left(25 \mathrm{mg} / \mathrm{m}^{2}\right)$, and methotrexate $\left(12 \mathrm{mg} / \mathrm{m}^{2}\right)$ X 3 days and vincristine $\left(1.5 \mathrm{mg} / \mathrm{m}^{2}\right)$ X 2 days or cyclophosphamide $\left(500 \mathrm{mg} / \mathrm{m}^{2}\right)$, actinomycin $\mathrm{D}\left(0.5 \mathrm{mg} / \mathrm{m}^{2}\right)$, and bleomycin $\left(12 \mathrm{mg} / \mathrm{m}^{2}\right) \mathrm{X} 3$ days and vincristine $(1.5$ $\mathrm{mg} / \mathrm{m}^{2}$ ) X 2 days. A limb salvage procedure with tumor resection and intraoperative 
radiation therapy was performed in May 1998. After tumor resection, she received six additional chemotherapy courses (same as above), and resection of the lung metastasis was performed. She is currently at the end of therapy.

The patient was born after a full-term pregnancy to a healthy mother and father with no consanguinity. She has one younger brother (12 years old) who is phenotypically normal. The patient had a normal childhood development. She had regular menstruations since the age of 10 years until the second course of chemotherapy.

She had a height of $157 \mathrm{~cm}$ and a weight $50 \mathrm{~kg}$, and physical examination revealed normal secondary sex characteristics, and axillary and pubic hair.

\section{CYTOGENETIC FINDINGS}

A peripheral blood sample was obtained on 3 March 1998 and cultured for 72 hours in the presence of phytohemag-glutinin. Conventional chromosome analysis with $G$ banding revealed 47,XXXc in all the 50 metaphases examined as the single chromosomal aberration observed (Fig. 1).

\section{MOLECULAR FINDINGS}

After total RNA extraction, nested reverse transcriptase-polymerase chain reaction (RTPCR) with the appropriate primers for EWS and FLI1/ERG genes was performed [3]. After RT-PCR, DNA fragments were blotted onto nylon membranes (Hybond+, Amersham-Pharmacia Biotech, Buckinhamshire, UK), and Southern analysis was performed with the appropriate chemoluminescent internal probes [4].

The molecular analysis was performed on both the primary tumor and the lung metastasis, showing, in both cases, the presence of EWS-FLI1 type 1 transcripts (EWS exon 7 joined in frame with exon 6 of FLI1; Fig. 2).

\section{DISCUSSION}

Females with the 47,XXXc karyotype, first reported in 1959 [5], present a tendency to be tall and thin, and many of them appear to be completely normal. The estimated frequency of this syndrome in the general population is roughly 1 in 1000 women [6]. Females with more than three $X$ chromosomes are extremely rare. Some triple- $X$ women show a tendency toward mental retardation, psychosis, or both, and some educational or behavioral problems. Although some of them have menstrual difficulties, many menstruate regularly and are fertile. Moreover, the presence of an additional X chromosome may interfere in the gonadal potential, and $\mathrm{X}$ aneuploidy has been reported to be involved in primary ovarian failure [7]. 
Studies of inheritance and expression of X-linked genes suggest that the origin of the extra X chromosome in 47,XXXc females is usually nondisjunction in meiosis I of the mother, and a maternal age effect also was noted [8]. In this case, all the other family members were phenotypically normal, and the origin of the extra X chromosome could not be ascertained.

Recent reviews of chromosomal aberrations in Ewing sarcoma report few cases of patients being carriers of X-chromosome aberrations [2]; and, to our knowledge, this is the first case of a Ewing sarcoma in a germ-line carrier of a karyotype with a trisomy of chromosome X.

Although the association between Ewing sarcoma and X trisomy in this patient may be a random finding, a longer series of Ewing sarcoma should be screened to get more information about eventual germ-line chromosomal aberrations that do not involve important phenotypic manifestations and would therefore be underestimated.

\section{REFERENCES}

1. Delattre O, Zucman J, Melot T, Garau XS, Zucker JM, Lenoir GM, Ambros PF, Sherer D, Turc-Carel C, Triche TJ, Aurias A, Thomas G (1994): The Ewing family of tumors: a subgroup of small round cell tumors defined by specific chimeric transcripts. N Engl J Med 331:294-299.

2. Sandberg AA, Bridge JA (1994): The Cytogenetics of Bone and Soft Tissue Tumors. R. G. Landes Co., Austin.

3. Downing JR, Head DR, Parham DM, Douglass EC, Hulshof MG, Link MP, Motroni TA, Grier HE, Curcio-Brint AM, Shapiro DN (1993): Detection of the $(11 ; 22)(q 24 ; q 12)$ translocation of Ewing's sarcoma and peripheral neuroectodermal tumor by reverse transcription polymerase chain reaction. Am J Pathol 143:1294-1300.

4. Pfleiderer C, Zoubek A, Gruber B, Kronberger M, Ambros PF, Lion T, Fink FM, Gadner H, Kovar H (1995): Detection of tumor cells in peripheral blood and bone marrow from Ewing tumor patients by RT-PCR. Int J Cancer 64:135139.

5. Jacobs PA, Baikie AG, Court Brown WM, Macgregor TN, Maclean N, Harnden DG (1959): Evidence of the existence of the human "super female." Lancet 2:423-425.

6. Hamerton JL, Canning N, Ray M, Smith S (1975): A cytogenetic study of 14,069 newborn infants: incidence of chromosome abnormalities. Clin Genet 8:223-243.

7. Collen RJ, Falk RE, Lippe BM, Kaplan SA (1980): A 48,XXXX female with absence of ovaries. Am J Med Genet 6:275-278.

8. Morton WE, Wu D, Jacobs PA (1988): Origin of sex chromosome aneuploidy. Ann Hum Genet 52:85-92. 
1

2

影

唱

38

点

s 18

146

7

10

11

12

6

站

(5)

है

औै:

83

13

15

16

17

18

$83 \quad 38$

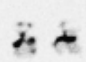

(2) 3

है को है

20

21

22

Figure 1. Patient's karyotype showing the presence of the triple $X$ as the single chromosomal aberration.

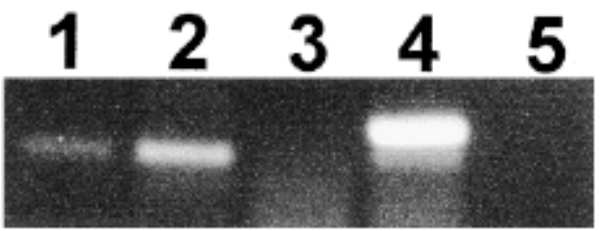

\section{EWS}

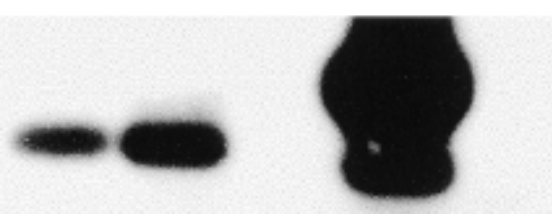

\section{FLI1}

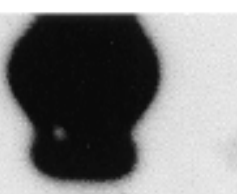

Figure 2. Mount showing RT-PCR results (upper) that were transferred and hybridized with internal probes for EWS (middle) and FLI1 genes (lower). Lanes 1 and 2 correspond to the primary tumor and metastasis, respectively, and show identical 329bp bands corresponding to EWS-FLI1 type 1 transcripts. Lane 3: Benign pleural tumor used as a negative control. Lane 4: Extraskeletal Ewing sarcoma displaying a 398-bp band corresponding to an EWS-FLI1 type 2 transcript. Lane 5: Negative RT-PCR control performed without RNA template. 